\title{
IMPLEMENTASI UNDANG-UNDANG NOMOR 35 TAHUN 2014 TENTANG PERLINDUNGAN HAK ATAS PENDIDIKAN BAGI ANAK DIDIK WARGA BINAAN SOSIAL (WBS) (Studi di Kantor UPT. Pelayanan Sosial Anak Padangsidimpuan)
}

\author{
Abdul Aziz Abidan ${ }^{1}$ \\ ${ }^{1}$ Fakultas Hukum Universitas Muhammadiyah Tapanuli Selatan, Sumatera Utara
}

\begin{abstract}
ABSTRAK
Tujuan penelitian ini adalah untuk mendeskripsikan perencanaan implementasi hak anak didik warga binaan sosial untuk mendapatkan pendidikan di sekolah. Adapun faktor-faktor yang mendukung implementasi perlindungan hak atas pendidikan bagi anak didik warga binaan sosial yaitu anak asuh panti asuhan mendapatkan pendidikan agama, serta pendidikan umum lainnya yang mengajarkan perilaku lemah lembut, pencegahan melakukan kekerasan, memperluas ilmu pengetahuan, dan melakukan penanaman karakter bagi warga binaan sosial dilingkungan sekolah. UPT. Pelayanan sosial anak juga berperan aktif agar warga binaan sosial tetap menjaga berperilaku disekolah, warga binaan sosial juga diberikan bimbingan bagaimana berperilaku maupun bergaul dengan lingkungan sekolah agar pendidikan anak warga binaan sosial nantinya memiliki hasil untuk masa depan warga binaan sosial. Penelitian ini menggunakan sumber data dari kepala UPT. Pelayanan Sosial Anak Padangsidimpuan, maupun pejabat fungsional, dan staf lainnya. Teknik pengumpulan data menggunakan wawancara, observasi, dan arsip atau dokumentasi. Metode penelitian digunakan secara field research dengan memakai teknik pengumpulan data dengan melalui wawancara (interview) dan mengamati dokumen-dokumen dan arsip yang diberikan oleh pihak terkait. Anak warga binaan sosial mendapatkan pendidikan yang layak.Warga binaan sosial diberikan pendidikan yang bagus dari sekolah dan juga diberikan pendidikan di dalam asrama berupa keterampilan lainnya . Pemberian pendidikan bantuan berupa Dana BOS atau Beasiswa. Diberikan pembinaan kepada anak asuh berupa pendidikan di dalam asrama seperti bimbingan keagamaan, bimbingan sosial,, bimbingan konseling.
\end{abstract}

Kata Kunci: Perlindungan, Hak, Pendidikan Anak Binaan Sosial

\section{PENDAHULUAN}

Harapan dari generasi suatu bangsa terutama adalah anak. Melalui proses pendidikan, anak diberi pelatihan untuk mengembangkan kreativitas untuk meningkatkan keterampilannya agar menjadi sumber daya manusia yang mampu bersaing di era globalisasi saat ini. Namun berdasarkan realita yang ada banya anak-anak yang mengalami putus sekolah, hal ini disebabkan oleh beberapa faktor diantaranya, faktor ekonomi (kemiskinan), faktor lingkungan, faktor internal anak. Keberadaan anak terlantar dan anak kurang mampu diakui dan dilindungi oleh Undang-Undang Dasar 1945 Pasal 34 ayat 1 yang berbunyi "Fakir miskin 
dan anak terlantar dipelihara oleh negara" dan Pasal 34 ayat 2 yang berbunyi "Negara mengembangkan sistem jaminan sosial bagi seluruh rakyat dan memberdayakan masyarakat yang lemah dan tidak mampu sesuai dengan martabat kemanusiaan” dan Pasal 34 ayat 3 yang berbunyi "serta negara bertanggung jawab atas penyediaan fasilitas pelayanan kesehatan dan fasilitas pelayanan umum yang layak”.

Anak adalah manifestasi orang dewasa. Sama halnya dengan orang dewasa, anak juga mendapatkan hak sebagai seorang manusia dalam posisinya sebagai subjek hukum. Oleh karena itu, hak-hak yang melekat padanya haruslah dijunjung tinggi dan dilindungi agar anak dapat tumbuh menjadi pribadi yang bermanfaat. Perlindungan hak anak menjadi penting, karena anak adalah manusia yang utuh, yang oleh karenanya memiliki hak secara asasi. Perlindungan anak dengan demikian merupakan bagian dari pelaksanaan Hak Asasi Manusia (Supeno, 2010).

Konvensi Hak Anak yang merupakan bagian dari HAM menegaskan dan membentuk hakhak yang secara kategoris terdiri dari empat macam, yakni hak atas kelangsungan hidup (survival rights),hak atas perlindungan (protection rights), hak atas perkembangan (development rights), dan hak untuk berpartisipasi (participation rights). (Muhammad, 1999). Kewajiban mengimplementasikan hak anak tersebut terdapat dalam Undang-Undang Nomor 35 Tahun 2014 tentang Perlindungan Anak. Dalam hal perlindungan atas pendidikan, telah menegaskan bahwa: "setiap anak berhak memperoleh pendidikan dan pengajaran dalam rangka pengembangan pribadinya dan tingkat kecerdasannya sesuai minat dan bakatnya”. Hak atas pendidikan diperoleh oleh seluruh anak dan harus diusahakan oleh negara dengan memberikan kesempatan seluas-luasnya. Hak atas pendidikan melingkupi semua anak dengan berbagai latar belakang dan status sosial anak, termasuk anak yang kurang mampu secara ekonomi untuk mendapatkan pendidikan.

Anak didik warga binaan sosial adalah suatu lembaga usaha kesejahteraan sosial yang mempunyai tanggung jawab untuk memberikan pelayanan kesejahteraan sosial kepada anak terlantar atau kurang mampu untuk melaksanakan penyantunan dan pengentasan anak terlantar, memberikan pelayanan pengganti fisik, mental, dan sosial pada anak asuh. Agar anak-anak kurang mampu dan terlantar tetap memiliki bekal imu pengetahuan (skills) meski putus sekolah, pemerintah tidak sedikit mengadakan program untuk mendapatkan penghidupan yang layak bagi mereka. Agar mereka dapat lebih percaya diri, mandiri serta tidak ketergantungan dengan orang lain. ( Sutrisno, 1999)

Salah satu upaya pemerintah dalam melindungi anak-anak kurang mampu dan terlantar tersebut adalah adanya Panti Sosial, yang merupakan lembaga yang didirikan oleh 
pemerintah maupun swasta yang bertujuan untuk membantu seseorang yang mengalami disfungsi sosial agar dapat melaksanakan fungsi sosialnya secara wajar, salah satu lembaga yang dapat melaksanakan rehabilitasi sosial bagi anak-anak kurang mampu dan terlantar. yang dimaksud adalah melakukan pemulihan dan pengembangan yang bertujuan untuk mengembalikan keberfungsian secara fisik, mental, sosial serta memberikan dan meningkatkan keterampilan.

Perlindungan terhadap hak pendidikan bagi anak didik warga binaan sosial tersebut harus mendapatkan perhatian khusus dari pemerintah mengingat status sosial yang dijalani. Unit Pelayanan Sosial Anak sebagai perpanjangan tangan dari pemerintah dan negara, harus memberikan perlindungan khusus kepada anak yang kurang mampu secara ekonomi ataupun terhalang untuk mendapatkan pendidikan. Hal ini sejalan dengan Pasal 53 ayat (1) UndangUndang Nomor 35 tahun 2014 Tentang Perlindungan Anak yang berbunyi: "Pemerintah dan Pemerintah Daerah bertanggung jawab untuk memeberikan biaya pendidikan dan/atau bantuan cuma-cuma atau pelayanan khusus bagi Anak dari Keluarga kurang mampu, Anak terlantar, dan Anak yang bertempat tinggal di daerah terpencil.

Dinas sosial Provinsi Sumatera Utara dibawah naungan Pemerintah Provinsi mendirikan Unit Pelayanan Teknis (UPT) Pelayanan Sosial Anak yang beralamatkan di Jl. Mawar Nomor 1 Kota Padangsidimpuan yang merupakan tempat untuk membina anak-anak yang mengalami putus sekolah akibat ketidakmampuan di bidang ekonomi. Dalam pelaksanaan tugas Pelayanan Sosial Anak memiliki fungsi memberikan pelayanan sosial kepada anak-anak yang putus sekolah, terlantar atau mengalami permasalahan sosial agar mampu hidup mandiri dan terhindar dari berbagai masalah sosial bagi dirinya dan lingkungannya berupa pelayanan fisik maupun pelayanan kebutuhan seorang anak, agar anak dapat memiliki potensi sehingga dapat melaksanakan fungsi sosialnya.

Pelayanan Sosial Anak memiliki tujuan tertentu, yaitu:”menghindari anak-anak dari berbagai sosial sebagai akibat dari putus sekolah dan terlantar serta untuk mewujudkan generasi muda yang berprestasi dan mampu mengembangkan potensi dirinya dan bermanfaat masyarakat”. (Sunafiah, 1999: 40).

Pelayanan Sosial Anak juga memberikan berupa pendidikan diluar asrama yaitu dengan bisa belajar pengetahuan umum di sekolah umum, mulai dari tingkat SD, SMP, SMA dan SMK di daerah Kota Padangsidimpuan yang bertujuan agar anak-anak Warga Binaan Sosial (WBS) bisa bersosialisasi langsung terhadap lingkungan umum. Penelitian ini dilakukan dengan tujuan yaitu untuk mengetahui perlindungan hak atas pendidikan bagi anak didik warga 
binaan sosial sesuai dengan hukum positif yang berlaku.Untuk mengetahui peran pelayanan sosial anak dalam meningkatkan mutu pendidikan bagi anak.

\section{METODE}

Jenis penelitian yang digunakan pendekatan Normatif Empiris, yaitu penelitian yang dilakukan berdasarkan pengembangan literatur serta melihat fakta yang di implementasikan di lapangan berdasarkan data primer atau yang disebut penelitian lapangan (field research). Penegertian populasi. Menurut Hadari (1990) yang dimaksud dengan populasi adalah: "Keseluruhan Obyek penelitian yang dapat terdiri dari manusia, benda-benda, hewan, tumbuh-tumbuhan, gejala-gejala nilai test, peristiwa-peristiwa sebagai sumber daya dimiliki karakteristik tertentu di dalam suatu penelitian”. Adapun yang menjadi populasi dalam penelitian ini adalah Tenaga Struktural UPT. Pelayanan Sosial Anak Kota Padangsidimpuan. Sampel adalah sebagian dari populasi yang dianggap dapat mewakili populasinya

\section{HASIL DAN PEMBAHASAN}

Sejarah Panti Asuhan UPT. Pelayanan Sosial Anak Padangsidimpuan Awalnya adalah Panti Asuhan ( Rumah Miskin ) pada tahun 1950, yang berlokasi di Jalan Imam Bonjol Padangsidimpuan. Dinamakan rumah miskin karena mengingat pada saat itu masih zaman pergolakan, banyak anak-anak indonesia yang sengsara dan menderita akibat penjajahan, sehingga untuk menjaga kelangsungan hidup anak didirikanlah Rumah Miskin sebagai tempat penampungan anak yatim, yatim piatu dan terlantar.

Cita-cita yang terkandung dalam Pasal 34 UUD 1945 yaitu “Agar setiap warga negara tidak hidup dalam keadaan fakir miskin dan bebas dari ketelantaran anak-anak”. Adapun usaha Pemerintah dibidang Kesejahteraan Sosial antara lain yaitu bimbingan, pembinaan dan Rehabilitasi Sosia kepada Warga Negara yang terganggu kemampuan untuk mempertahankan hidup yang terlantar ataupun tersesat. Pemeliharaan tarap Kesejahteraan Sosial melalui penyelenggaraan suatu sistem jaminan sosial.

UPT. Pelayanan Sosial Anak Padangsidimpuan adalah salah satu Unit Pelaksana Tehnis Dinas Sosial provinsi Sumatera Utara khususnya dalam upaya memberi pelayanan, pembinaan dan mengurangi angka putus sekolah ( buta aksara ) bagi anak terlantar, kurang mampu sesuai dengan UUD 1945 Pasal 34 yaitu "Fakir Miskin dan anak Terlantar diperlihara oleh Negara”. 


\section{Peranan dalam Membina Karakter Anak Asuh}

Pola pengasuhan merupakan bentuk perlakuan atau tindakan untuk memelihara, melindungi, mendampingi, mengajar dan membimbing anak asuh selama masa perkembangan untuk pola pikir dan pengetahuan. Menginjak masa anak-anak dan remaja, sejumlah sikap, nilai dan keterampilan berinteraksi sosial dicapai sebagai kompetensi. Kemampuan manusia untuk belajar merupakan karakteristik penting yang membedakan manusia dengan makhluk hidup lainnya.

Unit Pelaksana Tehnis (UPT) Pelayanan sosial Anak Padangsidimpuan adalah salah satu unit Pelaksana Tehnis Dinas Sosial provinsi Sumatera Utara khusususnya dalam upaya memberi pelayanan, pembinaan, dan mengurangi angka putus sekolah (buta aksara) bagi anak terlantar, kurang mampu sesuai dengan UUD 1945 Pasal 34 yaitu "Fakir miskin dan anak terlantar dipelihara oleh negara”.

Tugas pokok UPT. Pelayanan Sosial Anak Padangsidimpuan sesuai dengan Peraturan Gubernur Sumatera Utara bahwa tugas pokok Dinas Kesejahteraan dan Sosial Provinsi sumatera Utara adalah melaksanakan urusan pemerintah daerah atau kewenangan provinsi dibidang potensi sumber Kesejahteraan Sosial, pemberdayaan sosial, pelayananan dan rehabilitasi sosial, perlindungan sosial dan jaminan sosial serta tugas pembantuan.

Fungsi Pelayanan Sosial memiliki beberapa fungsi yaitu sebagai berikut :

a. Perumusan kebijakan teknis di bidang potensi sumber kesejahteraan sosial, pemberdayaan sosial, rehabilitasi sosial, perlindungan sosial, dan jaminan sosial.

b. Penyelenggaraan urusan pemerintahan dan pelayanan umum dibidang potensi sumber kesejahteraan sosial, pemberdayaan sosial, pelayanan dan rehabilitasi social perlindungan sosial dan jaminan sosial.

c. Pelaksanaan pemberi perizinan dibidang kesejahteraan social

d. Pembinaan dan pelaksanaan tugas di bidang kesejahteraan social

e. Pelaksanaan tugas pembantuan di bidang kesejaheraan social

f. Pelaksanaan pelayanan administrasi internal dan eksternal

g. Gambaran Umum UPT. Pelayanan sosial Anak Padangsidimpuan

Tabel 1.1 Keadaan Personil UPT. Pelayanan Sosial Anak Padangsidimpuan

\begin{tabular}{|l|l|l|}
\hline No. & Personil UPT. Pelayanan sosial Anak & Jumlah \\
\hline 1. & Struktural & 4 orang \\
\hline 2. & Fungsioanl & 2 orang \\
\hline 3. & Perawat & 1 orang \\
\hline 4. & Ahli gizi & 1 orang \\
\hline 5. & Staff & 8 orang \\
\hline & Jumlah PNS & 17 orang \\
\hline
\end{tabular}


Jumlah Instruktur UPT. Pelayanan Sosial Anak Padangsidimpuan Tahun 2019

\begin{tabular}{|l|l|l|}
\hline No. & Instruktur UPT. Pelayanan Sosial Anak & Jumlah \\
\hline 1. & Instruktur Bahasa Inggris & 1 orang \\
\hline 2. & Instruktur Komputer & 1 orang \\
\hline 3. & Instruktur salon/Pangkas & 1 orang \\
\hline 4. & Instruktur Mental & 1 orang \\
\hline 5. & Instruktur Fisik & 1 orang \\
\hline 6. & Instruktur Kesehatan & 2 orang \\
\hline 7. & Instruktur Masak & 2 orang \\
\hline & Jumlah & 9 orang \\
\hline
\end{tabular}

Tenaga Outsourching UPT. Pelayanan Sosial Anak Padangsidimpuan

\begin{tabular}{|l|l|l|}
\hline No.` & Tenaga Outsourching & Jumlah \\
\hline 1. & Tenaga Keamanan & 2 orang \\
\hline 2. & Tenaga Kebersihan & 2 orang \\
\hline & Jumlah & 4 orang \\
\hline
\end{tabular}

Jumlah Warga Binaan Sosial UPT. Pelayanan Sosial Anak Padangsidimpuan

\begin{tabular}{|l|l|l|}
\hline No. & Warga Binaan Sosial & Jumlah \\
\hline 1. & Tingkat SD & 10 orang \\
\hline 2. & Tingkat SMP & 36 orang \\
\hline 3. & Tingkat SMA & 31 orang \\
\hline & Jumlah & 77 orang \\
\hline
\end{tabular}

Warga Binaan Sosial bersekolah di luar lingkungan asrama dan sebagian bersekolah di Sekolah Pemerintah (Negeri) dan Swasta sesuai kemampuan nilai dan keinginanan yang diperoleh warga binaan sosial (WBS).

a) Kondisi gedung asrama UPT. Pelayanan Sosial Anak Padangsidimpuan, jumlah kamar tidur Warga Binaan Sosial, yaitu :

1. Kamar tidur Laki-Laki 5 Unit yang dihuni 31 orang

2. Kamar tidur Perempuan 6 Unit yang dihuni 39 orang

Warga Binaan Sosial yang berada di UPT. Pelayanan Sosial Anak Padangsidimpuan berasal dari beberapa Kabupaten/Kota yaitu :
a. Kota Padangsidimpuan
b. Kabupaten Padang Lawas
c. Kabupaten Padang Lawas Utara
d. Kabupaten Mandailing Natal
e. Kabupaten Tapanuli Selatan 
Sarana UPT. Pelayanan Sosial Anak Padangsidimpuan

Adapun gedung/bangunan yang terdapat di UPT. Pelayanan Sosial Anak Padangsidimpuan, terdiri dari :

Tabel 2.1 Gedung/bagunan UPT. Pelayanan Sosial Anak Padangsidimpuan

\begin{tabular}{|l|l|l|}
\hline No. & Gedung/ Bagunan & Jumlah \\
\hline 1. & Gedung, Kantor & 1 Unit \\
\hline 2. & Rumah Dinas & 1 Unit \\
\hline 3. & Asrama & 1 Unit \\
\hline 4. & Mushollah & 1 Unit \\
\hline 5. & Dapur/Ruang Makan/Aula & 1 Unit \\
\hline 6. & Ruang Perpustakaan & 1 Unit \\
\hline 7. & Ruang Salon & 1 Unit \\
\hline 8. & Ruang Kesehatan & 1 Unit \\
\hline 9. & Ruang Komputer & 1 Unit \\
\hline 10. & Ruang Keamanan & 1 Unit \\
\hline 8. & Gudang & 2 Unit \\
\hline & Jumlah & 12 Unit \\
\hline
\end{tabular}

Program Kerja Pelayanan Sosial Anak bagi Warga Binaaan Sosial

Tanggung jawab untuk memenuhi kebutuhan fisik, fisikologis dan sosial anak merupakan tanggungjawab utama orangtua. Anak-anak yang tidak memiliki orangtua mempunyai hak untuk diasuh oleh negara atau lembaga lain. Anak dimaksud adalah seseorang yang berusia dibawah umur 18 tahun. Anak balita adalah anak yang berusia dibawah 5 tahun.

Anak terlantar adalah anak yang tidak terpenuhi kebutuhannya secara wajar baik fisik, mental, spritual maupun sosial. Faktor penyebab terjadinya anak terlantar adalah tidak adanya orangtua, orangtua bercerai, konflik perang atau keadaan darurat dan terkena musibah bencana alam. Sistem pelayanan UPT. Pelayanan Sosial Anak Padangsidimpuan yaitu :

a. Tahap penjangkauan yang melibatkan sosialisasi tentang program Panti asuhan di masyarakat.

b. Tahap pengenalan dan pemahaman masalah yang mencakup analisis keadaan klien, keadaan keluarga, lingkungan tempat tinggal.

c. Tahap perencanaan bantuan yang akan diberikan termasuk tujuan, jenis, sumber daya yang akan digunakan dalam pembahasan kasus.

d. Tahap pelaksanaan program yang meliputi bimbingan sosial, fisik, kesehatan, fsikologis (mental) keterampilan dan dukungan pendidikan di sekolah.

e. Tahap bimbingan lanjut atau pelayanan lanjutan.

f. Terminasi yang meliputi penghentian pelayanan terhadap warga binaan sosial (pemutus kontrak/pengembalian ke pihak keluarga). 
Tugas Pokok UPT. Pelayanan Sosial Anak Padangsimpuan

Tugas pokok untuk memberikan pelayanan dan bimbingan sosial, fisik, psikologis, agama, kesehatan , keterampilan dan pendidikan di sekolah bagi anak usia sekolah supaya anak pintar, berkualitas dan mampu berperan aktif di lingkungan masyarakat.

Fungsi utama UPT. Pelayanan Sosial Anak Padangsidimpuan Fungsi utama adalah pusat pelayanan kesejahteraan sosial, pusat pengembangan kesempatan kerja, pusat informasi kesejahteraan sosial, dan lembaga pendidikan.

Fungsi Tehnis UPT. Pelayanan Sosial Anak Padangsidimpuan

Fungsi tehnis adalah motivasi, observasi, identifikasi, seleksi dan penerimaan calon warga binaan sosial. Memiliki daya tampung, pengasramaan dan perawatan kepada warga binaan sosial. Warga binaan sosial diberikan pembinaan fisik dan mental maupun psikologis serta bimbingan sosial individu maupun kelompok, penyiapan dan pelaksanaan pemberian sandang dan pangan, dan menyediakan pelayanan kesehatan bagi warga binaan sosial. Pelaksanaan terminasi ( Pemulangan ) kepada keluarga, masyarakat/lingkungan kerja jika warga binaan sosial tidak mematuhi peraturan yang ada dan menyelenggarakan fungsi pengadministrasi dan kerumah tanggaan.

Pelaksanaan kegiatan Pendidikan bagi Anak Warga Binaan Sosial

Sebagaimana uraian diatas bahwa UPT.Pelayanan Sosial Anak Padangsidimpuan melaksanakan tugas dan fungsinya agar dapat merealisasikan tujuan yang akan dicapai dengan melakukan kegiatan/fungsi tehnis dan administrasi.

\section{Kegiatan Tehnis Operasional}

1. Melaksanakan pendekatan awal pada calon warga binaan sosial, orangtua dan keluarga.

2. Mengadakan sosialisasi ke Kabupaten/Kota.

3. Menerima warga binaan sosial di UPT. Pelayanan Sosial Anak Padangsidimpuan.

4. Memberikan bimbingan sosial, fisik, psikologis, agama, kesehatan, keterampilan (pendekatan ilmu teknologi komputer dan salon pria dan wanita, serta kursus bahasa inggris).

5. Mendaftarkan serta melaksanakan penempatan warga binaan sosial ke sekolahsekolah negeri maupun swasta (SDN, SMP, SMAN, SMKN/ Swasta) yang berkerja sama dengan Dinas Pendidikan Kota Padangsidimpuan.

6. Melakukan koordinasi dengan UPT. Panti Sosial Bina Remaja Tanjung Morawa. 
7. Melakukan koordinasi dengan pemerintah setempat untuk tambahan pendidikan pelatihan bidang keterampilan lainnya yang ada di UPT. Pelayanan Sosial Anak Padangsidimpuan.

Kegiatan Administrasi Umum

1. Ketatausahaan adalah melaksanakan urusan surat menyurat, ekspedisi, kearsipan dan urusan perpustakaan, laporan kegiatan dan membuat data lengkap warga binaan sosial yang akurat dan valid.

2. Kerumahtanggan yakni melaksankan pengasramaan serta menyediakan sarana dalam asrama dan memelihara perlengkapan UPT. Pelayanan Sosial Anak dengan menggunakan Dana APBD dan bantuan Dana dari Yayasan Dharmanis Pusat.

Kepala UPT. Pelayanan Sosial Anak Padangsidimpuan

Kepala UPT. Pelayanan Sosial Anak Padangsidimpuan yaitu Bapak Romoden Lubis SH., MH dan seluruh pegawai melakukan bimbingan setiap hari senin pada minggu ke-2 setiap bulannya. Dalam pelaksanaan ini Ka.UPT. Pelayanan sosial Anak menekankan agar dapat mengikutiaturan-aturan dilingkungan asrama yaitu mengikuti seluruh kegiatan sesuai jadwal antara lain piket WBS, ibadah WBS, Kegiatan WBS.

Disiplin warga binaan sosial di asrama harus senantiasa di tegakkan, sehingga kepatuhan akan aturan-aturan dapat berjalan sebagaimana mestinya. Disamping itu juga kepatuhan akan peraturan di luar asrama harus juga dipelihara ditegakkan warga binaan sosial tidak boleh keluar asrama tanpa izin dari security ataupun petuga sosial lainnya.

Kegiatan Pekerja Sosial bersama Pengasuhan

Kegiatan pekerja sosial bersama pengasuhan UPT. Pelayanan Sosial Anak Padangsidimpuan memiliki beberapa kegiatan di antaranya sebagai berikut :

1. Bimbingan sosial kepada seluruh warga binaan sosial yang dilaksanakan pada hari Senin minggu ke tiga setiap bulannya, dalam bimbingan sosial ini bagian pengasuhan dan peksos warga binaan sosial wajib mengikuti seluruh kegiatan (ibadah sholat).

2. Kegiatan rohani, pembelajaran bahasa inggris, keterampilan salon/pangkas, komputer, fisik yaitu senam dan bela diri tapak suci dan gotong royong, dan memelihara kebersihan dan lingkungannya pekarangan seperti kebersihan kamar mandi, tempat tidur, belakang kamar, dan tumbuhan yang da di depan kamar warga binaan sosial yang diawasi oleh ibu asuh masing-masing kamar. 
3. Dalam pelaksanaan bimbingan sosial Seksi Pengasuhan dan Pekerja Sosial juga memberikan dukungan dan menumbuhkan kesadaran, tanggungjawab sosial dan menumbuhkan kemauan, kemampuan untuk menyesuaikan diri, bekerja sama dalam lingkungan juga mampu melaksanakan fungsi sosialnya, agar mereka tidak merasa rendah diri dalam pergaulan sehari-hari, dan pengembalian jati diri warga binaan sosial saat sedang berada di luar lingkungan asrama.

4. Memotivasi anak-anak untuk mendorong semangat mereka dalam mengikuti setiap kegiatan yang telah diprogramkan seperti kegiatan keterampilan komputer, keterampilan salon, bimbingan fisik dan bimbingan mental setra bimbingan kesehatan.

\section{Kegiatan Rutin oleh Warga Binaan Sosial}

Kegiatan rutin yang dilakukan oleh warga binaan sosial di lingkungan asrama adalah :

1. Kegiatan keterampilan computer

Kegiatan keterampilan komputer dilaksanakan pada hari senin selasa dan jum'at Pukul 16.00 s/d 17.00 untuk warga binaan sosial tingkat SMP dan SMA wajib mengikuti keterampilan komputer. Dalam kegiatan ini anak-anak diajarkan tentang bagaimana menjalankan aplikasi komputer, penggunaan microsoft, mengetik surat, dll. Warga binaan sosial juga sudah diajarkan sampai pada tahap Microsoft Office Exel.

\section{Kegiatan Keterampilan Salon}

Keterampilan salon dilaksanakan setiap hari kamis dan hari sabtu pukul 16.00 s/d 17.30 WIB yang didampingi oleh instruktur. Pada hari kamis pangkas dilaksanakan oleh anak laki-laki dan hari sabtu kegiatan salon untuk anak perempuan. Dalam kegiatan salon warga binaan social yang terlibat adalah SMP s/d SMA, mereka diajarkan secara manual (menggunakan gunting) dan alata elektrik (mesin cukur) untuk pangkas. Pangkas laki-laki diajarkan juga dengan berbagai model gaya rambut.

Kegiatan keterampilan salon perempuan diperkenalkan dengan berbagai peralatan salon dan warga binaan sosial sudah mampu melakukan makeup, creambath, dan kriting rambut dengan baik, sampai dengan saat ini hampir 60\% sudah pada tingkat mahir. UPT. Pelayanan Sosial Anak Padangsidimpuan juga melakukan kerjasama dengan balai pelatihan kerja, untuk warga binaan sosial yang terminasi akan diupayakan mendapatkan sertifikat keterampilan salon. 


\section{Kegiatan Fisik Secara rutin}

kegiatan fisik yang dilakukan adalah senam setiap hari minggu pada pukul $06.00 \mathrm{~s} / \mathrm{d}$ 08.00, yang diikuti oleh seluruh warga binaan sosial (WBS). Kegiatan yang dilakukan oleh warga binaan sosial diikuti mulai tinggat SMP dan SMA. Ada juga WBS yang mengikuti kegiatan Gulat sebagai atlet Kota Padangsidimpuan dan pernah menjuarai Piala Gubsu dengan peringkat II dan Piala Walikota yang dilaksanakan di Tanjung Balai.

\section{Kegiatan Kerohanian}

Kegiatan rohani meliputi Ibadah sholat 5 waktu, Muhadaroh setiap malam senin, Yasinan setiap malam jum’at, pengajian Iqro’ dan Al-qur’an tiga kali dalam seminggu. Anak-anak belajar tajwid dan diajarkan cara membaca Al-qur'an dengan baik dan benar dan ini dipantu oleh instruktur dari Kemenag Kota Padangsidimpuan.

\section{Kursus Bahasa Inggris}

Pemberian kursus bahasa inggris dilaksanakan dua kali seminggu dengan jadwal pada hari Senin jam 16.00 s/d 17.00 WIB untuk warga binaan sosial tingkat SMP, dan pada hari Jum'at dengan waktu yang sama untuk warga binaan sosial tingkat SMA. Dalam kegiatan kursus bahasa inggris pada saat ini WBS mulai mahir dengan berbahasa Inggris untuk perkenalan lingkungan aasrama, peralatan dapur dan peralatan kamar. Instrusktur dari tenaga pendidik salah satu SMA yang ada di Kota Padangsidimpuan.

6. Kegiatan Kebersihan

Kegiatan kebersihan setiap pagi diadakan kebersihan kamar masing-masing, lingkungan asrama dengan dibentuknya piket warga binaan sosial setiap hari. Mengadakan gotong royong bagi warga binaan sosial setiap hari minggu di lingkungan asrama yang di dampingi oleh pengasuh.

7. Kesehatan dan Gizi

Program kesehatan yang sudah dilakukan di UPT. Pelayanan Sosial Anak Padangsidimpuan yaitu penyuluhan kesehatan yang dilakukan setiap hari kamis pukul 14.30s/d 15.30 WIB berupa :

a. Penyuluhan tentang perilaku hidup bersih sehat (PHBS) dan praktek seperti cara mencuci tangan, menggosok gigi, mencuci rambut dan merapikan tempat tidur.

b. Penyuluhan tentang berbagai penyakit seperti diare, demam berdarah, gastristis (sakit lambung), batuk, cacingan dll.

c. Praktek tentang pengobatan sederhana yang dapat dilakukan di rumah (terutama saat warga binaan sosial pulang kampung) yaitu pengobatan diare, batuk, luka dan demam.

d. Evaluasi kesehatan (berat badan, tinggi badan, pemeriksaan fisik) sekali 6 bulan. 
e. Pemberian vitamin C, vitamin B12, vitamin B6

f. Pemberian obat cacing sekali 6 bulan

g. Pemeriksaan kuku warga binaan sosial.

h. Pemeriksaan masalah kulit rambut wagra binaan sosial

Program gizi yang sudah dilakukan di UPT. Pelayanan Sosial Anak Padangsidimpuan yaitu dengan sosialisasi gizi yang dilaksanakan pada hari jum’a minggu keempat setiap bulannya dari jam 17.00 s/d 18.00 WIB yang wajib diikuti oleh semua warga binaan sosial. Materi yang diberikan terkait dengan pengetahuan dan pemahaman tentang Zat Gizi Makro (Karbohidrat, Protein dan Lemak), Zat Gizi Mikro (Vitamin dan Mineral), cara memotong sayur yang benar, serta pengolahan masakan yang baik.

Pemenuhan gizi seimbang yaitu terkait dengan menu makanan sehari-hari, karena menu makanan di UPT. Pelayanan Sosial Anak Padangsidimpuan sudah mencakup baik walaupun belum bisa digolongkan sempurna. Bahan-bahan masakan yang diperoleh oleh warga binaan sosial adalah sebagai berikut :

a. Karbohidrat : dipenuhi dengan pemberian nasi yang berasal dari beras dengan kualitas yang cukup baik.

b. Protein hewani : dalam satu minggu sekali daging sapi, sekali danging ayam dan sekali telur, dan empat kali ikan.

c. Protein nabati : olahan tahu dan tempe

d. Sayuran : berupa daun singkong, kangkung dan sawi hijau

e. Selingan : berupa bubur kacang hijau, buah dan roti

Untuk menunjang pemenuhan gizi anak-anak dibutuhkan dana yang cukup untuk mengupayakan pemberian makanan yang baik sesuai dengan kebutuhan. Namun terkait dengan dana yang tidak memadai menjadi kendala yang cukup serius untuk dapat melengkapi kebutuhan gizi Warga Binaan Sosial.

Keuangan untuk Warga Binaan Sosial

Tabel 3.1 Pengeluaran Anggaran untuk warga binaan sosial Padangsidimpuan

\begin{tabular}{|l|l|c|l|}
\hline No. & Pengeluaran Anggaran & Jumlah & Persentase \\
\hline 1. & Jumlah pagu anggaran kegiatan operasional & Rp. 977.539.456,- & $100 \%$ \\
\hline 2. & Realisasi Keuangan Rutin & Rp. - & - \\
\hline 3. & Realisasi Fisik & Rp. - & - \\
\hline
\end{tabular}


Kerjasama dengan Instansi Terkait

a. Dinas Pendidikan

Kerjasama UPT. Pelayanan Sosial Anak Padangsidimpuan dengan Dinas pendidikan telah terjalin yaitu setiap Warga Binaan Sosial telah diterima bersekolah di sekolah Negeri sesuai dengan tingkat pendidikannya, meringankan biaya uang sekolah dan Warga Binaan Sosial menerima dana BLSM (Bantuan Langsung Siswa Miskin).

b. Dinas Kesehatan

Kerjasama UPT. Pelayanan Sosial Anak Padangsidimpuan dengan Dinas Kesehatan telah terjalin yaitu setiap Warga Binaan Sosial telah diberikan pengobatan gratis dan setiap Warga Binaan Sosial yang sakit parah bisa membuat rujukan ke Rumah Sakit Umum Padangsdimpuan.

Hambatan dari UPT. Pelayanan Sosial Anak Padangsidimpuan adalah kebutuhan lemari pakaian, tilam, bantal, sprei, dan tempat tidur sangat mendesak karena peralatan yang ada sudah rusak dan tidak layak pakai. Kebutuhan air bersih belum terpenuhi untuk keperluan sehari-hari sehingga sangat mendesak untuk pembuatan sumur bor dan tower air. Pemecahan dan kesimpulan adalah memanfaatkan peralatan apa adanya dan semoga kebutuhan dalam hambatan tersebut agar Bapak Kepala Dinas Sosial Provinsi Sumatera Utara dapat mempertimbangkannya supaya dapat terpenuhi kebutuhan di UPT. Pelayanan Sosial Anak Padangsidimpuan.

\section{PEMBAHASAN}

Hasil penelitian menunjukkan bahwa terdapat beberapa aspek bahwa warga binaan sosial tetap mendapatkan hak-hak anak dan kewajiban anak untuk mendapatkan pendidikan gratis dari pemerintah setempat dan didukung dari bantuan bantuan sosial lainnya yaitu Dinas Kesejahteraan Sosial Provinsi Sumatera Utara dan juga dari lembaga sosial yang memberikan bantuan kepada warga binaan sosial. Warga binaan sosial yang memiliki prestasi dan bakat akan diberikan wawasan pengetahuan yang lebih dari UPT. Pelayanan Sosial Anak Padangsidimpuan dan setiap anak- anak yang telah masuk sekolah diberikan pilihan sejolah sesuai dengan keinginan mereka, agar anak- anak warga binaan sosial bisa lebih semangat dalam mengembangkan ilmu pengetahuan mereka.

Berdasarkan beberapa hasil penelitian yang sudah dilakukan di atas terbukti bahwa pemerintah wajib memberikan bantuan berupa anggaran setiap tahunnya agar warga binaan sosial dapat menjalankan aktifitas sehari-hari dengan dapat bersekolah, menjalankan 
pengetahuan tambahan di dalam asrama seperti belajar salon, komputer, bahkan belajar khursus bahasa inggris dan juga memberikan konsumsi bagi anak-anak warga binaan sosial agar tumbuh kembang anak warga berjalan sesuai yang diinginkan.

Pelayanan sosial anak memberikan perlindungan terhadap hak pendidikan bagi anak warga binaan sosial dan harus mendapaatkan perhatian khusus dari pemerintah yang mengingat status sosial yang dijalani. Unit pelayanan sosial anak adalah sebagai tangan dari pemerintah dan negara dan memerikan perlindungan khusus kepada anak yang kurang mampu atau terlantar dan hal ini juga sejalan dengan Pasal 53 ayat (1) Undang-Undang Nomor 35 tahun 2014 Tentang perlindungan anak yang berbunyi "Pemerintah dan Pemerintah Daerah bertanggung jawab untuk memberikan biaya pendidikandan/atau bantuan Cuma-Cuma atau pelayanan khusus bagi anak dari keluarga kurang mampu, anak terlantar, dan anak bertempat tinggal di daerahg terpencil.

Dalam menjalankan tugas Pelayanan Sosial Anak mereka memberikan pelayanan sosial bagi anak- anak yang putus sekolah, anak yatim/piatu/yatim piatu, anak terlantar atau mengalami masalah sosial agar mampu hidup mandiri dan terhindar dari berbagai masalah sosial bagi dirinya dan lingkungan berupa fisik maupun pelayanan kebutuhan seorang anak, agar anak dapat memiliki potensi sehingga dapat menjalankan fungsi sosialnya atau menjalankan aktifitasnya sehari-hari seperti layakna anak pada umumnya.

Pelayanan sosial anak juga memberikan pendidikan atau keterampilan lebih kepada anakanak agar warga binaan sosial memiliki pandangan yang luas, yang bertujuan menghidari anak-anak dari permasalahan sosial sebagai akibat putus sekolah dan terlantar serta anakanak tetap memiliki prestasi dan mampu mengembangkan potensi dirinya dan bermanfaat bagi dirinya sendiri.

\section{KESIMPULAN}

Anak warga binaan sosial menapatkan pendidikan yang layak.Warga binaan sosial diberikan pendidikan yang bagus dari sekolah dan juga diberikan pendidikan di dalam asrama berupa keterampilan lainnya .Pemberian pendidikan bantuan berupa Dana BOS atau Beasiswa. Diberikan pembinaan kepada anak asuh berupa pendidikan di dalam asrama seperti bimbingan keagamaan, bimbingan sosial,, bimbingan konseling. 


\section{DAFTAR PUSTAKA}

Arikunto, 2003, Prosedur Penelitian Pendidikan, Jakarta: Rineka Cipta

Budi Wibhawa, 2010, Dasar-Dasar Pekerja Sosial, Bandung: Widya Padjadjaran

Danuredjo, 1997, Otonomi Indonesia Ditinjau dalam Rangka Kedaultan, Jakarta: Penerbit Laras.

Edi Suharto, 1997, Kebijakan Sosial \& Pekerjaan Sosial, Bandung: LSP STKS

Erni Fitri Astuti, 2013, Aspek dalam perlindungan Hukum Pada Anak, Jakarta.

Fattah, Nanang, 2000, Ekonomi dan Pembiayaan Pendidikan, Bandung. Remaja Rosdakarya

Fuadi, 2010, Tujuan Departemen Sosial, Jakarta: Citra Aditya Bakti

Hadi Supeno, 2010, Deskriminasi Anak: Transformasi Perlindungan Anak Berkonflik dengan Hukum, Jakarta:Komisi Perlindungan Anak Indonesia (KPAI)

H.A.R Tilaar, 1999, Aspek yang Mendukung tentang Kebijakan Pendidikan, Jakarta: Media Sarana

Kementerian sosial, 2010, Paduan Umum Program Kesejahteraan Sosial, Jakarta.

Koesoemahatmadja, 1979, Pengantar ke Arah Sistem Pemerintah di Daerah di Indonesia, Bandung: Binacipta

Muhammad, Joni dan Zuchina Z Tamnas, 1999, Aspek Hukum Perlindungan Anak dalam Prespektif Konvensi Hak Anak, Bandung: Citra Aditya Bakti

Prodjodikoro Wirjono, 2002, Asas-Asas Hukum Pidana Di Indonesia, Bandung: Refika Aditama.

Sekamto dalam Endar, 2014, Peran Sosiologi, Jakarta: Rajawali Pers 